\title{
Expression of gingival crevicular fluid markers during early and late healing of intrabony defects after surgical treatment: a systematic review
}

\author{
V. P. Koidou ${ }^{1}$ (D) - G. S. Chatzopoulos ${ }^{1} \cdot$ I. Tomas $^{2} \cdot$ L. Nibali ${ }^{1} \cdot$ N. Donos ${ }^{1}$ \\ Received: 16 April 2019 / Accepted: 22 September 2019 /Published online: 7 November 2019 \\ (C) The Author(s) 2019
}

\begin{abstract}
Background Surgical treatments such as guided tissue regeneration (GTR) and access flap surgery are widely employed for the treatment of intrabony defects. However, little is known regarding the postoperative expression of gingival crevicular fluid (GCF) markers.

Objective The aim of this systematic review was to compare the expression of GCF markers following treatment of periodontal intrabony defects with guided tissue regeneration or access surgery. The association of the markers' expression with the clinical outcome was also assessed.

Methods An electronic literature search was conducted in MEDLINE, EMBASE, OpenGrey, LILACS and Cochrane Library up to December 2018 complemented by a manual search. Human, prospective clinical studies were identified. The changes from baseline up to 30 days (early healing) and 3 months (late healing) were assessed.

Results A total of 164 publications were identified and reviewed for eligibility. Of these, 10 publications fulfilled the inclusion criteria. The included studies evaluated 15 different GCF markers with a follow-up time between 21 and 360 days postoperatively. PDGF, VEGF and TIMP-1 changes were often investigated in the included studies; however, contrasting results were reported. Two studies agreed that both GTR and OFD lead to similar OPG level changes. TGF- $\beta 1$ is increased early postoperatively, irrespective of the surgical technique employed.

Conclusion There is limited evidence available on the expression of GCF markers after surgical interventions of intrabony periodontal defects. However, OPG and TGF- $\beta 1$ tend to increase early post-operatively, irrespective of the surgical technique employed, irrespective of the surgical technique employed.

Clinical relevance More well-designed, powered studies with sampling periods reflecting the regenerative process are needed, and future research should focus on employing standardised protocols for collecting, storing and analysing GCF markers.
\end{abstract}

Keywords Gingival crevicular fluid · Markers · Guided tissue regeneration · Open flap debridement

Electronic supplementary material The online version of this article (https://doi.org/10.1007/s00784-019-03088-4) contains supplementary material, which is available to authorized users.

\section{P. Koidou}

v.koidou@qmul.ac.uk

1 Centre for Oral Immunobiology and Regenerative Medicine and Centre for Oral Clinical Research, Institute of Dentistry, Queen Mary University London (QMUL), London, United Kingdom

2 Oral Sciences Research Group, Health Research Institute Foundation of Santiago (FIDIS), Universidade de Santiago de Compostela, Santiago de Compostela, Spain

\section{Introduction}

Periodontitis is a chronic inflammatory disease caused by bacterial biofilm that leads to a progressive destruction of the supporting apparatus of a tooth and eventually to tooth loss. The prevalence of periodontitis, according to the 2009-2010 data from the National Health and Nutrition Examination Survey (NHANES), reaches $46 \%$ in US adults [1].

As periodontal disease progresses, it results in bone loss that can be horizontal or vertical or a combination of both. The loss of supporting bone vertically results in the formation of intrabony defects that progressively worsen and are associated with an increased probability of tooth loss [2]. While non- 
surgical periodontal therapy is effective in improving the clinical parameters, such as probing pocket depth (PPD) and clinical attachment levels (CAL) [3], surgical approaches are more effective - in particular for PPD of more than $6 \mathrm{~mm}$ $[4,5]$. Currently, intrabony defects are identified as sites favourable for periodontal regeneration $[6,7]$ with the most commonly used techniques being guided tissue regeneration (GTR) and enamel matrix derivatives (EMD) presenting with similar clinical outcomes which are superior to open flap debridement (OFD) and osseous surgery (OS) [8-11].

However, irrespective of the regenerative modality employed for the treatment of intrabony defects, little is known regarding the processes and sequences involved in the periodontal regeneration and consequently, in the postoperative expression of angiogenesis, regeneration and inflammation markers in the gingival crevicular fluid (GCF) that accompany these processes [12]. The expression of such markers postoperatively may define whether the healing process moves towards a regenerative or a reparative direction [12]. Understanding the cellular and biological events in periodontal wound healing can possibly provide useful information in identifying predictable regenerative treatment for the periodontium.

The aim of this systematic review was to investigate the healing patterns of intrabony defects after surgical interventions (GTR, OS, OFD, EMD) by means of angiogenesis, regeneration and inflammation markers detected in the GCF before and early ( $\leq 30$ days) or late ( 3 months) after the surgical intervention. Furthermore, the association of the expression of the GCF markers with the clinical outcome was investigated.

\section{Materials and methods}

\section{Protocol and Registration}

The present systematic review followed the PRISMA (Preferred Reporting Items for Systematic Review and MetaAnalyses) guidelines [13] (Supplemental Material 1) and was registered with PROSPERO under the ID number CRD42018115794.

\section{PICO question}

The PICO question (patient, intervention, comparison and outcome) formulated was: "In patients with periodontal intrabony defects, does the expression of GCF markers for angiogenesis, regeneration and inflammation differ when treated with GTR employing a membrane and/or bone graft and/or biologics (e.g. EMD) (test group(s)) compared with intrabony defects treated with access surgery [OFD or OS or apically positioned flap (APF)] (control group) early $(\leq 30$ days) and late (3 months) after the surgical intervention?"

\section{Eligibility criteria}

\section{Types of studies}

Human, prospective clinical studies assessing the expression of angiogenesis, regeneration and inflammation markers in the GCF were considered. Only studies with at least ten patients per group were included. No language restriction was set.

\section{Population}

Systemically healthy individuals with chronic periodontitis (CP) with at least one tooth with PPD $\geq 5 \mathrm{~mm}, \mathrm{CAL}$ and evidence of radiographic bone loss or aggressive periodontitis $[14,15]$ or periodontitis stages III or IV [16] and contributing a minimum of 1 intrabony defect.

\section{Intervention and comparison}

Intrabony defects treated with GTR employing a membrane and/or bone graft and/or with biologics (e.g. Emdogain) (test group(s)) and intrabony defects treated with access flap surgery (OFD or OS or APF) (control group). No restriction related to the flap technique (minimally invasive or not) was applied to avoid omitting potentially relevant data. Intrabony defects treated with adjunct growth factors e.g. EMD were included in the test group(s).

\section{Outcome measures}

The primary outcome of this review was the change in the expression of angiogenesis, regeneration and inflammation markers in the GCF during early healing (from baseline up to 30 days) and during late healing (from baseline to at least 3 months postoperatively). Secondary outcomes considered were the association of the expression of GCF markers (early and/or late healing) with the clinical outcome, assessed with the use of surrogate measures such as PPD and/or CAL.

\section{Information sources and electronic search}

An electronic search was conducted by two independent reviewers (VK and GC) in MEDLINE, EMBASE, Cochrane Library, LILACS and OpenGrey for publications up to 10 December 2018. Combinations of controlled terms (MeSH and EMTREE) and keywords were utilised:

("infrabony" or "intrabony" or "infra-bony" or "intrabony" or "angular defect" or "periodontal defect") and ("guided tissue regeneration" or "GTR" or "periodontal regeneration" or "periodontal surgery" or "open flap debridement" or "OFD" or "access surgery") and ("gingival crevicular fluid" 
or "crevicular fluid" or "GCF" or "inflammatory marker" or "marker" or "growth factor" or "inflammatory mediator" or "biomarker")

Additionally, a manual search of periodontology-related journals including Journal of Dental Research, Journal of Clinical Periodontology, Journal of Periodontal Research and the Journal of Periodontology was performed from 2015 to 2018. The list of references in the publications included in this review as well as the list of references in relevant reviews were screened for potential additional publications fulfilling the inclusion criteria.

\section{Study selection}

The search results were initially screened for relevancy by means of title, keywords and abstract, independently and in duplicate by two reviewers (VK, GC). Irrelevant records were excluded at this stage. Any conflict was resolved with discussion. At the second round of screening, the full text of the publications remaining after the first round was assessed for inclusion in this review against the eligibility criteria described previously. The level of agreement between the two reviewers was calculated using Kappa statistics.

\section{Data collection process/data items}

The characteristics of the included publications were extracted by two reviewers (VK, GC). Among the details extracted were study characteristics (authors, journal of publication, year, country), number of patients, their demographics and risk factors (age, gender, smoking), diagnosis, number of intrabony defects, history of non-surgical treatment of the sites and time elapsed, characteristics of the included defects, surgical procedure employed (GTR, OFD), biomaterials used in the test group(s), postoperative care protocol, exposure rate, followup period, expression levels of the GCF markers, clinical outcomes (PPD, CAL), details of the methodology employed for the GCF sampling, storage, processing and detection of the markers, information regarding the main study outcome and power calculation of the study. When data from the included studies were missing, the authors of the publication were contacted through email.

\section{Risk of bias assessment}

The risk of bias of the included publications was assessed by the two reviewers independently and in duplicate. For the RCTs included, the quality of the selected publications was assessed according to the Cochrane Collaboration's tool for assessing risk of bias [17]. The selected publications were assessed for seven domains: sequence generation, allocation concealment, blinding of the participants and personnel, blinding of the outcome assessment, incomplete outcome data, free of selective outcome reporting and other sources of bias. For each of the individual domains, studies were classified as low, unclear or high risk of bias. Observational studies were assessed using the MINORS tool [18]. Studies were assessed in 12 items including clarity of the aim, inclusion of consecutive patients, prospective data collection, appropriateness of end points, unbiased assessment of study end points, appropriateness of follow-up time, inclusion of loss to follow-up rate, prospective calculation of the study size, comparable control group, contemporary control groups, baseline equivalence of groups on several factors and adequate statistical analysis. Each study may receive 0-2 points for each item and the total score ranges from 0 to 24 points. Studies with fewer than 16 points are considered of low quality, while high-quality studies need to have a score of greater than or equal to 16 .

\section{Results}

\section{Study selection}

The flowchart of the study selection and inclusion process is shown in Fig. 1. The initial search identified 68 MEDLINE, 110 EMBASE, 59 Cochrane database and 1 LILACS titles, with a total of 163 after duplicates' removal. One additional title was identified through hand search for a total of 164 titles. Following the screening of titles and abstracts by the two reviewers, 10 articles qualified for full text screening and all 10 met the inclusion criteria. The kappa value for interreviewer agreement was 0.99 at first round and 1.00 at second round.

\section{Study characteristics}

The characteristics of the included studies are presented in Table 1. All 10 included articles were in English. The study samples ranged from 12 [19] to 29 [20] patients. Seven of the included studies were randomised controlled clinical trials $[11,19-24]$ and the remaining 3 were prospective cohort studies $[12,25,26]$.

The characteristics of the included intrabony defects ranged from $\mathrm{PD} \geq 5 \mathrm{~mm}[12,20,24-26]$ to $\mathrm{PD} \geq 6 \mathrm{~mm}[11,19$, 21-23] and accompanying radiographic defect depth $\geq$ $3 \mathrm{~mm}[11,12,19,21,24], \geq 4 \mathrm{~mm}$ [20, 23] or unspecified $[22,25,26]$. The defects included were variations of 1-, 2-, 3wall defects [19, 24], only 2- or 3-wall defects [11, 21] or nonspecified in the majority of the investigations $[12,20,22,23$, $25,26]$.

The types of procedures included in the test group were GTR [11, 12, 21, 22, 24-26] GTR with EMD [19, 23], and minimally invasive surgical technique (MIST) with EMD [20]. Non-resorbable membranes that were removed 6 weeks postoperatively were utilised in 3 studies $[12,25,26]$. 
Fig. 1 PRISMA flow diagram

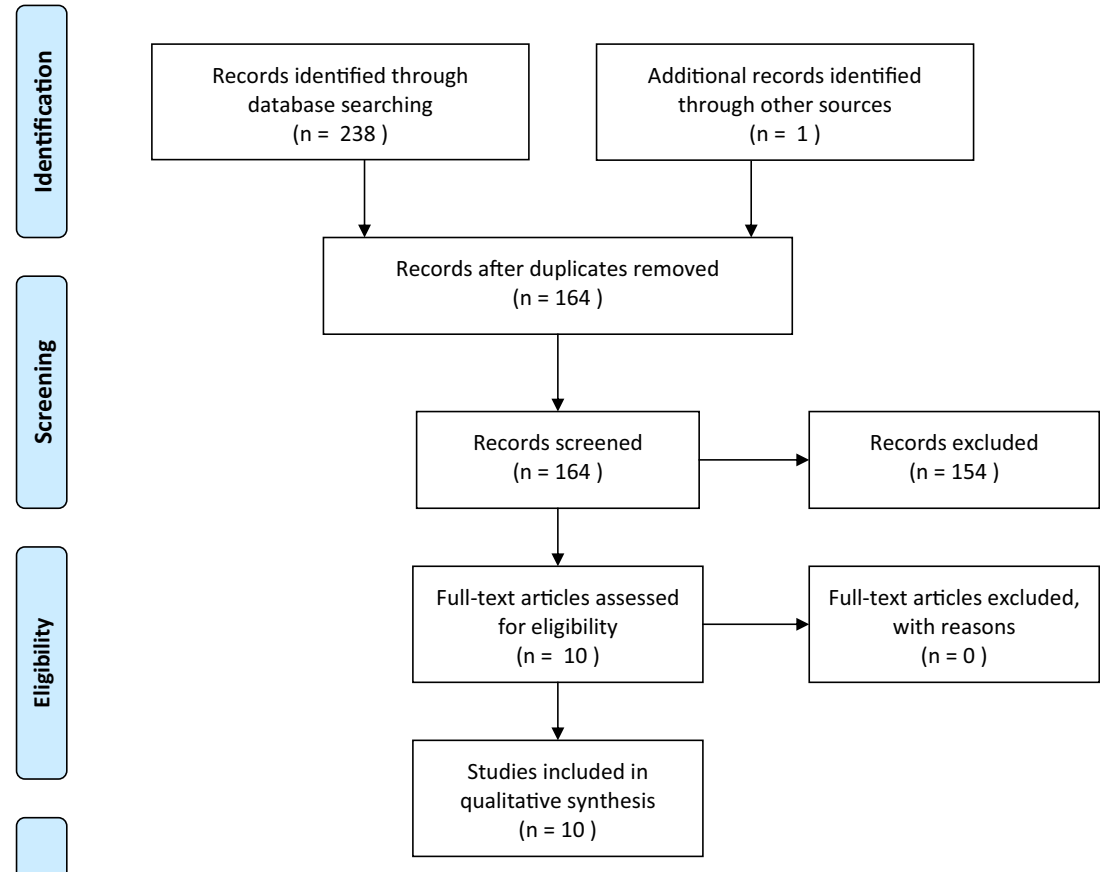

Five of the included studies utilised Periopaper for the sampling of the GCF [12, 19, 20, 22, 23], 3 studies utilised pre-cut chromatography strips (Whatman 3MM) [24-26] and 2 studies utilised micropipettes $[11,21]$. The GCF sampling time presented significant variation across studies, ranging from $30 \mathrm{~s}[12,20$, 22] to $1 \mathrm{~min}$ [23] and $2 \mathrm{~min}$ [24-26], while some studies allowed the insertion of the strip or the pipette until $5 \mu$ he pipette until [11, 21] with one study not reporting on the sampling time [19]. Regarding the storage of the samples, great variation was also observed: 2 studies stored their GCF samples at $-80{ }^{\circ} \mathrm{C}[19,23]$, 1 study at $-76^{\circ} \mathrm{C}[21], 4$ studies at $-70^{\circ} \mathrm{C}[22,24-26], 1$ study at $-26{ }^{\circ} \mathrm{C}[11]$ and 2 studies at $-20{ }^{\circ} \mathrm{C}[12,20]$. Eight of the included studies analysed the GCF samples using enzyme-linked immunosorbent assay (ELISA) [11, 12, 19-21, 23, 25, 26], 1 study used reverse-phase high-performance liquid chromatography with fluorimetric detection [22] and 1 study used multiplex beads assay [24]. Several GCF markers were investigated in the included studies. For facilitating the reader, the GCF markers were categorised under factors related with the healing of the epithelium, the connective tissue, the bone and others, even if some overlap might exist (Table 2).

The follow-up of the expression of GCF markers ranged from 21days [12] to 360 days [24], while the follow-up of the clinical parameters after treatment ranged from 90 [23] to 360 days [24]. However, there was rarely coincidence of the sampling times for the GCF markers with the clinical assessments postoperatively.

Finally, only 2 studies $[21,24]$ reported the postoperative occurrence of exposures. Gamal et al excluded the exposed sites from the study [21], while Rakmanee et al reported that 13 out of the 18 sites presented exposure of the membrane that was treated either with removal of the membrane ( 2 sites, classified as major exposure with size $>4 \mathrm{~mm}$ ) or with administration of antibiotics (2 sites, classified as minor) [24].

\section{Synthesis of results}

The results and conclusions of the individual studies included are presented in Table 2. Due to the significant heterogeneity of the included studies, in relation to the methodology employed, a meta-analysis was not performed.

\section{GTR}

Regarding GTR, 7 studies reported on the expression of GCF markers postoperatively [11, 12, 21, 22, 24-26]. Both Gamal, 2011 [11] and Gamal 2016 [21] employed the same GCF sampling method using a micropipette inserted at $2 \mathrm{~mm}$ depth in the sulcus and filled with $5 \mu \mathrm{L}$ of GCF. The samples were subsequently stored at $-76 \mathrm{C}$ and analysed with ELISA. The concentrations of platelet-derived growth factor-BB (PDGF-BB) peaked during the early stages of healing $(<14$ days) and decreased to baseline values by 30 days. Similarly, Rakmanee et al employing a different methodology, using pre-cut chromatography strips at the entrance of the gingival crevice for $2 \mathrm{~min}$ and stored at $-70 \mathrm{C}$, found again increased PDGF-AB amounts 7 days postoperatively that decreased to baseline levels after 42 days [24]. 


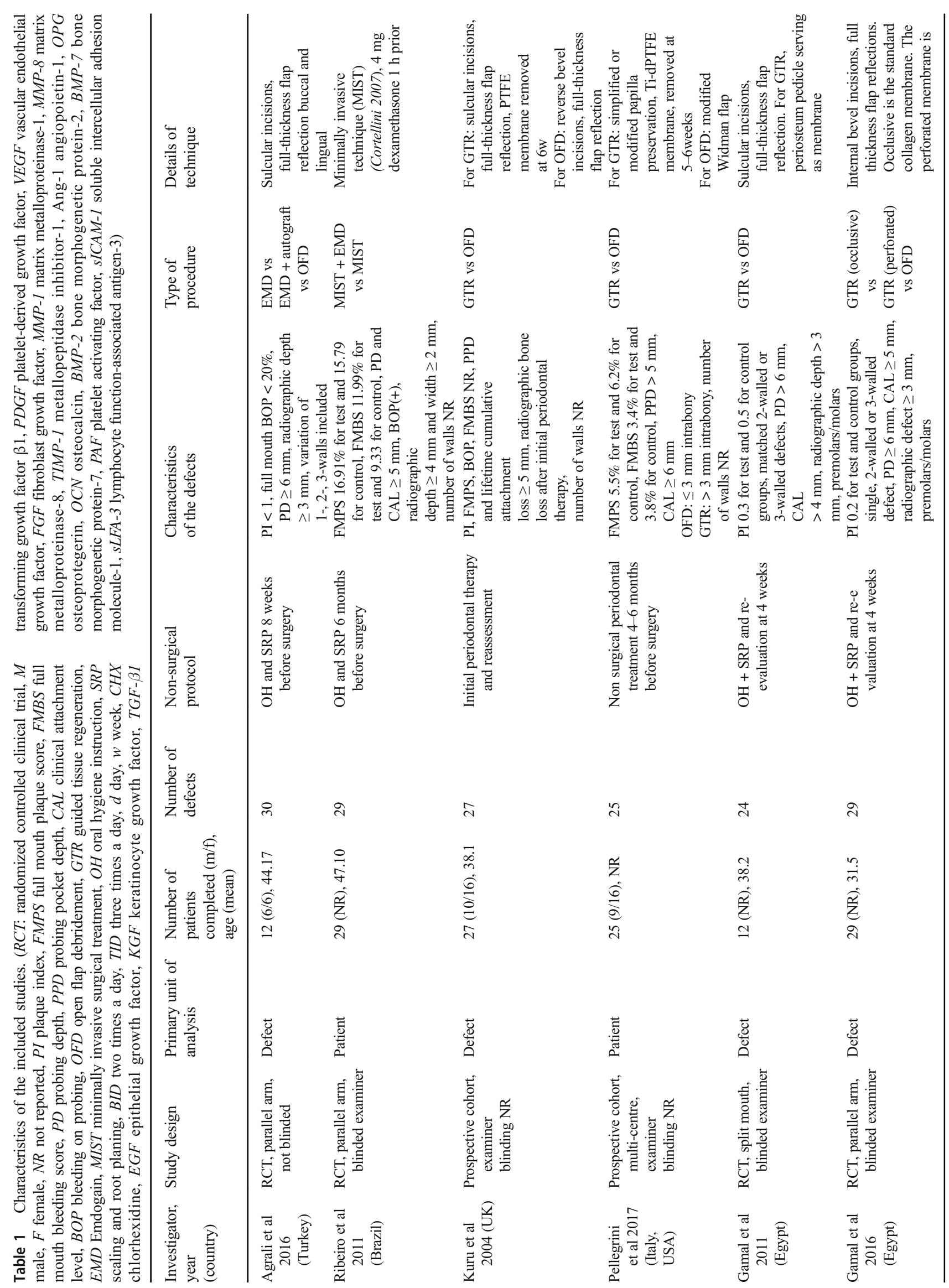




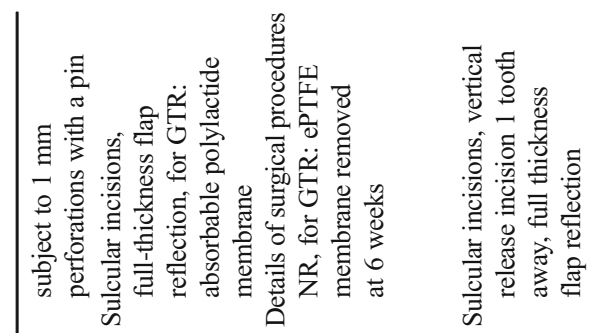

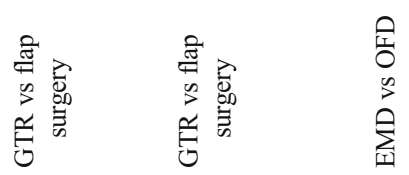

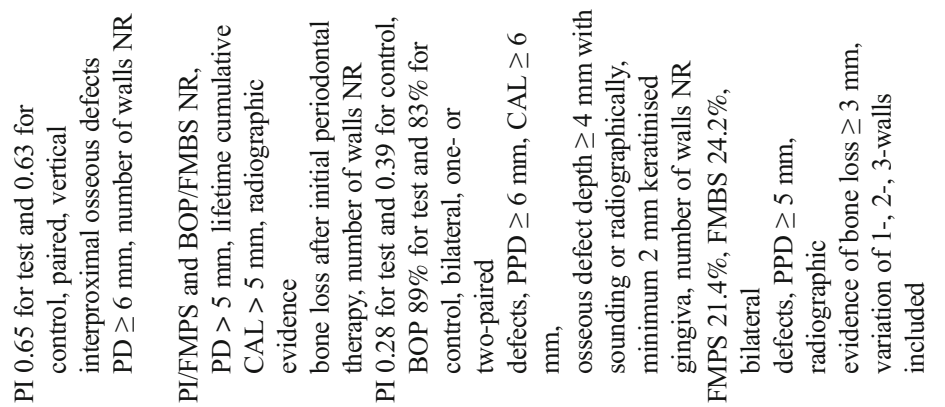

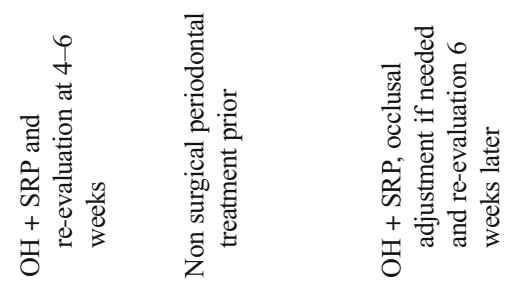

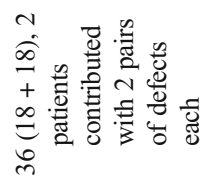

요 草

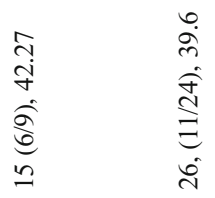

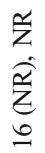

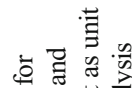

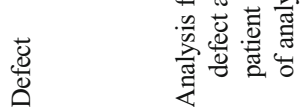

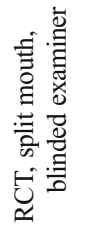

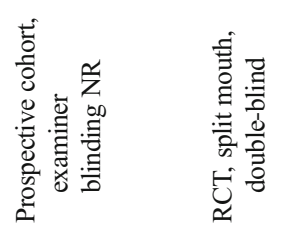

䓂

䓂

|

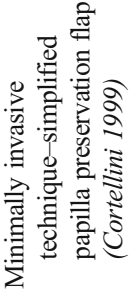

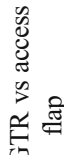
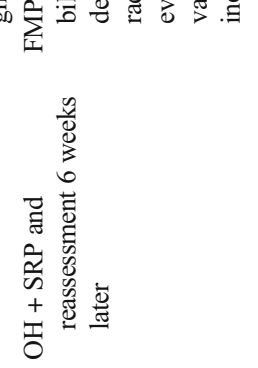

$\approx$

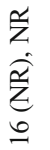

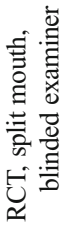

离

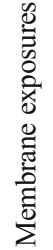

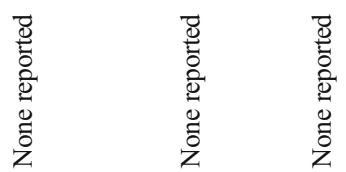

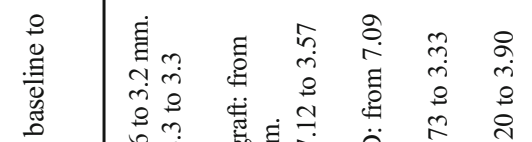

₹

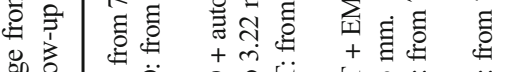

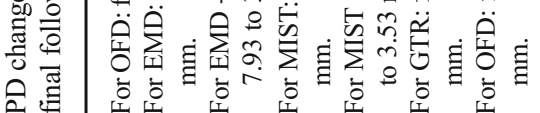



旁

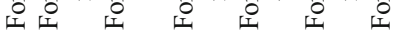

竞

s.

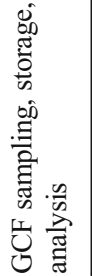

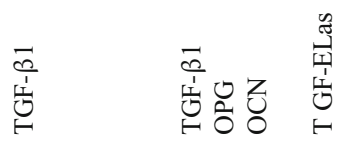

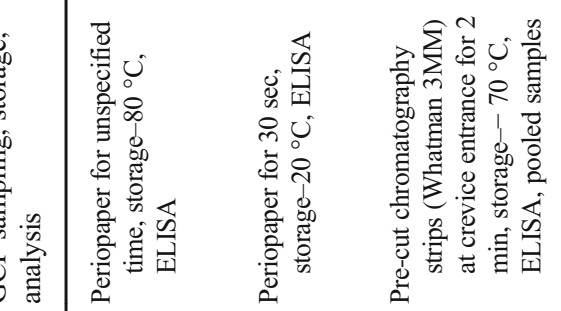

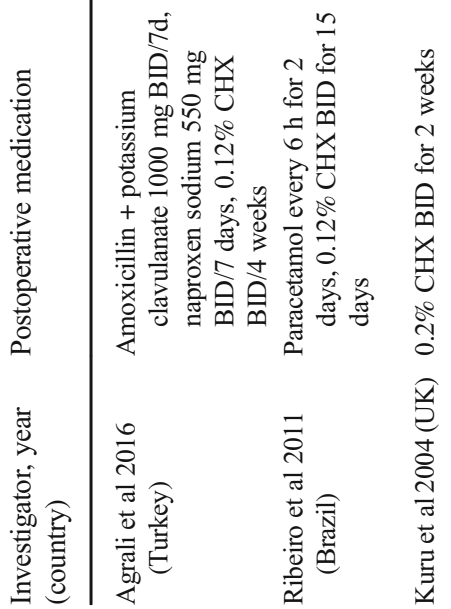




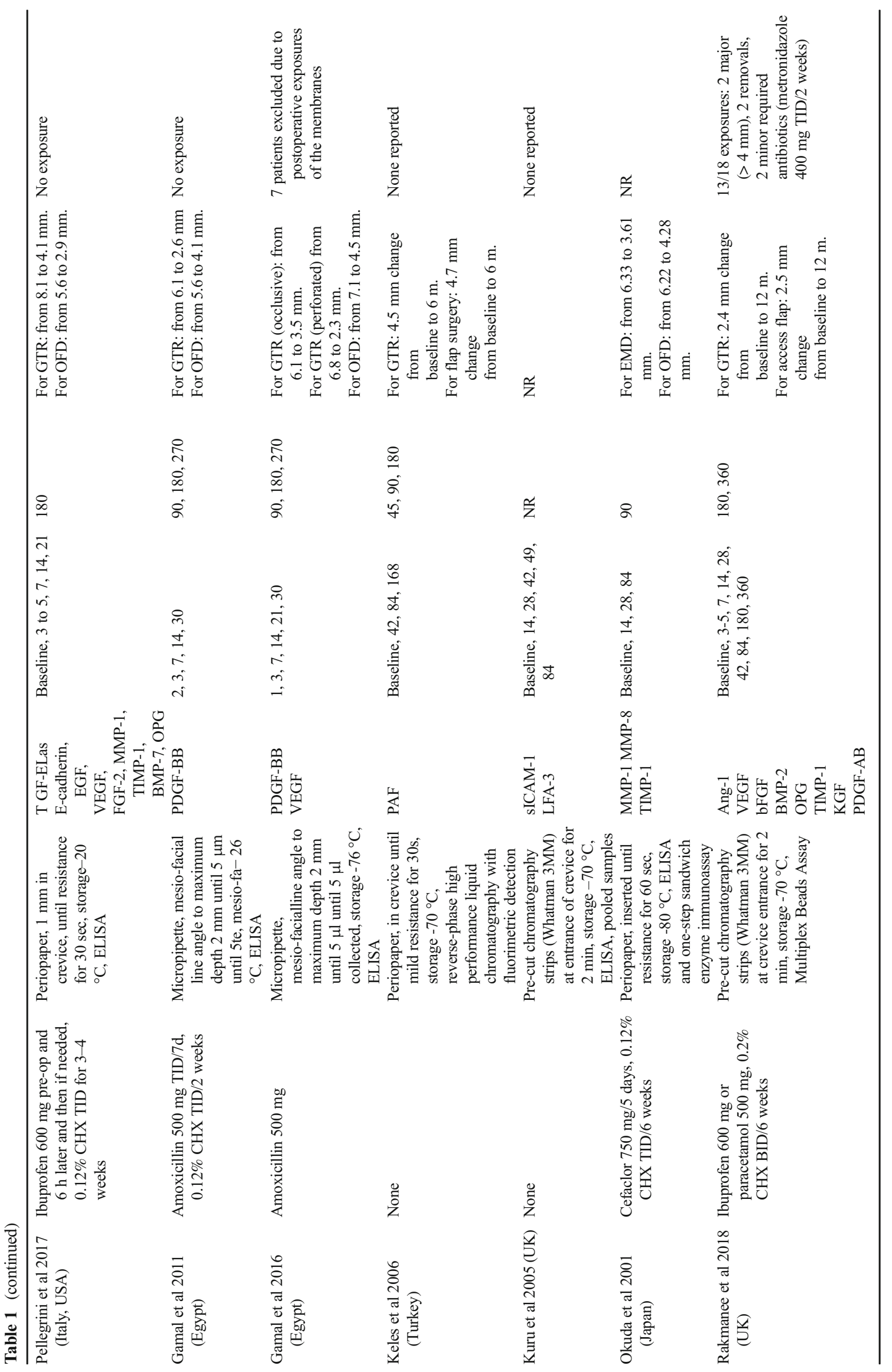


Furthermore, Rakmanee et al found similar PDGF-AB levels both after GTR and after OFD that were accompanied by a similar clinical response. However, the sites subjected to GTR were associated with high rates of exposure (13/18) that may have significantly affected the regenerative process and thus the clinical response observed.

Furthermore, Rakmanee et al reported that GCF osteoprotegerin (OPG) amounts significantly increased $2-3$ days postoperatively and subsequently declined [24]. No significant differences were noted between sites treated with GTR and sites treated with OFD. Pellegrini et al. using Periopaper inserted in the gingival crevice for $30 \mathrm{~s}$ found OPG levels to decrease following GTR and OFD; however, no comparison by treatment was reported for the change of the marker [12].

The expression levels of vascular endothelial growth factor (VEGF) were investigated by Rakmanee et al. [24] and Gamal et al. [21]. The former did not detect any significant difference in the change of VEGF GCF levels between sites treated with GTR and sites treated with access surgery using pre-cut chromatography strips [24]. However, the study by Gamal and co-workers, which used micropipettes, found that VEGF concentrations measured statistically significant higher concentrations in defects treated with OFD and GTR using a perforated membrane during the early postoperative period (days 1, 3 and 7) compared to defects treated using the occlusive membrane [21].

Kuru et al. 2004, using pre-cut chromatography strips at the entrance of the gingival crevice for $2 \mathrm{~min}$, found increased

Table 2 Summary of the conclusions of the included studies. (CAL clinical attachment level, $P D$ probing depth, $P P D$ probing pocket depth, $O F D$ open flap debridement, MIST minimally invasive surgical treatment, GTR guided tissue regeneration, vs versus, EGF epithelial growth factor, $K G F$ keratinocyte growth factor, $T G F-\beta G$ transforming growth factor $\beta 1, P D G F$ platelet-derived growth factor, $V E G F$ vascular endothelial growth factor, $F G F$ fibroblast growth factor, $M M P-1$ matrix transforming growth factor $\beta \mathrm{i}$ (TGF- $\beta 1$ levels 2 weeks postoperatively, that however were not statistically significant and declined to below baseline levels by 4 weeks [26]. The change in the TGF- $\beta 1$ levels was similar both after GTR and after OFD and accompanied a similar clinical response 6 months postoperatively.

\section{EMD}

Regarding EMD, 3 studies reported on the expression of GCF markers [19, 20, 23]. Ribeiro et al., using Periopaper in the gingival crevice until resistance was felt and for $30 \mathrm{~s}$, reported that TGF- $\beta 1$ levels in sites treated with MIST and EMD significantly increased by 15 days postoperatively and the levels decreased after 3 months [20]. Furthermore, the changes for TGF- $\beta 1$ levels were similar for sites treated with MIST and MIST with EMD and accompanied a similar clinical and radiographic response for both treatments. In contrast, Agrali et al. using Periopaper, inserted in the gingival crevice for unspecified amount of time, reported significantly higher TGF- $\beta 1$ levels for EMD-treated defects compared with OFD-treated defects 7 and 14 days postoperatively [19]. In the same line, the authors concluded that defects treated with EMD presented a superior clinical and radiographic improvement compared with defects treated with OFD. It is however worth noting that the majority of the defects treated with EMD

metalloproteinase-1, MMP-8 matrix metalloproteinase-8, TIMP-1 metallopeptidase inhibitor-1, Ang-1 angiopoietin-1, $O P G$ osteoprotegerin, $O C N$ osteocalcin, $B M P$-2 bone morphogenetic protein2, BMP-7 bone morphogenetic protein-7, $P A F$ platelet activating factor, sICAM-1 soluble intercellular adhesion molecule-1, sLFA-3 lymphocyte function-associated antigen-3)

FACTORS RELATED WITH THE HEALING OF EPITHELIUM

\begin{tabular}{|c|c|c|c|c|c|c|}
\hline GCF marker & $\begin{array}{l}\text { Investigato } \\
\text { r, Year }\end{array}$ & $\begin{array}{l}\text { Is periodontal } \\
\text { surgery leading to } \\
\text { significant changes } \\
\text { in the expression of } \\
\text { GCF markers? }\end{array}$ & $\begin{array}{l}\text { Is there any } \\
\text { significant difference } \\
\text { in the expression of } \\
\text { GCF markers for } \\
\text { intrabony defects } \\
\text { treated with GTR vs } \\
\text { OFD? } \\
\end{array}$ & $\begin{array}{l}\text { Is the study } \\
\text { powered for } \\
\text { GCF } \\
\text { markers, for } \\
\text { clinical } \\
\text { outcomes or } \\
\text { both? }\end{array}$ & $\begin{array}{l}\text { Is there any } \\
\text { significant difference } \\
\text { in the clinical } \\
\text { response for } \\
\text { intrabony defects } \\
\text { treated with GTR vs } \\
\text { OFD? }\end{array}$ & $\begin{array}{l}\text { Is the expression of GCF } \\
\text { markers directly associated } \\
\text { with clinically significant } \\
\text { changes following treatment? }\end{array}$ \\
\hline E-cadherin & $\begin{array}{l}\text { Pellegrini } \\
\text { et al } 2017\end{array}$ & $\begin{array}{l}\text { No significant change } \\
\text { observed for E- } \\
\text { cadherin for any group }\end{array}$ & Not reported & $\begin{array}{l}\text { No power } \\
\text { calculation } \\
\text { reported }\end{array}$ & $\begin{array}{l}\text { Higher percentage of } \\
\text { 'better responders' in } \\
\text { GTR vs OFD. }\end{array}$ & $\begin{array}{l}\text { No conclusion can be drawn } \\
\text { for the association of E- } \\
\text { cadherin with the clinical } \\
\text { outcome }\end{array}$ \\
\hline EGF & $\begin{array}{l}\text { Pellegrini } \\
\text { et al } 2017\end{array}$ & $\begin{array}{l}\text { EGF levels } \\
\text { significantly increased } \\
\text { post-op in GTR }\end{array}$ & Not & $\begin{array}{l}\text { No power } \\
\text { calculation } \\
\text { reported }\end{array}$ & $\begin{array}{l}\text { Higher percentage of } \\
\text { 'better responders' in } \\
\text { GTR vs OFD. }\end{array}$ & $\begin{array}{l}\text { No conclusion can be drawn } \\
\text { for the association of EGF with } \\
\text { the clinical outcome }\end{array}$ \\
\hline KGF & $\begin{array}{l}\text { Rakmanee } \\
\text { et al } 2018\end{array}$ & $\begin{array}{l}\text { KGF amounts } \\
\text { increased (non- } \\
\text { significantly) at } 7 \text { days } \\
\text { and decreased to } \\
\text { baseline levels for } \\
\text { GTR and access } \\
\text { surgery }\end{array}$ & $\begin{array}{l}\text { No significant } \\
\text { differences in KGF } \\
\text { amount between GTR } \\
\text { and access surgery. }\end{array}$ & $\begin{array}{l}\text { Powered for } \\
\text { clinical } \\
\text { outcomes }\end{array}$ & $\begin{array}{l}\text { No significant } \\
\text { differences for CAL } \\
\text { gain, PPD reduction, } \\
\text { radiographic bone fill } \\
\text { and radiographic } \\
\text { defect resolution for } \\
\text { GTR or access surgery }\end{array}$ & $\begin{array}{l}\text { The similar expression patterns } \\
\text { of KGF accompanied a similar } \\
\text { clinical response with GTR } \\
\text { and access surgery }\end{array}$ \\
\hline
\end{tabular}




\section{FACTORS RELATED WITH THE HEALING OF CONNECTIVE TISSUE}

\begin{tabular}{|c|c|c|c|c|c|c|}
\hline GCF marker & $\begin{array}{l}\text { Investigato } \\
\text { r, Year }\end{array}$ & $\begin{array}{l}\text { Is periodontal surgery } \\
\text { leading to significant } \\
\text { changes in the } \\
\text { expression of GCF } \\
\text { markers? }\end{array}$ & $\begin{array}{l}\text { Is there any significant } \\
\text { difference in the } \\
\text { expression of GCF } \\
\text { markers for intrabony } \\
\text { defects treated with } \\
\text { GTR vs OFD? }\end{array}$ & $\begin{array}{l}\text { Is the study } \\
\text { powered for } \\
\text { GCF } \\
\text { markers, for } \\
\text { clinical } \\
\text { outcomes or } \\
\text { both? }\end{array}$ & $\begin{array}{l}\text { Is there any } \\
\text { significant difference } \\
\text { in the clinical response } \\
\text { for intrabony defects } \\
\text { treated with GTR vs } \\
\text { OFD? }\end{array}$ & $\begin{array}{l}\text { Is the expression of } \\
\text { GCF markers directly } \\
\text { associated with } \\
\text { clinically significant } \\
\text { changes following } \\
\text { treatment? }\end{array}$ \\
\hline \multirow{4}{*}{ TGF- $\beta 1$} & $\begin{array}{l}\text { Agrali et al } \\
2016\end{array}$ & $\begin{array}{l}\text { GCF volume and TGF- } \\
\beta 1 \text { levels increased at } 7 \\
\text { days post-op and then } \\
\text { decreased to below } \\
\text { baseline levels (by } 90 \\
\text { days) for both EMD and } \\
\text { EMD + autograft }\end{array}$ & $\begin{array}{l}\text { TGF- } \beta 1 \text { could not be } \\
\text { detected in } 41 \% \text { of OFD, } \\
26 \% \text { of EMD and } 6 \% \text { of } \\
\text { EMD + autograft during } \\
\text { the follow up ( } 0 \text { to } 180 \\
\text { days). EMD and } \\
\text { EMD+autograft showed } \\
\text { significantly higher TGF- } \\
\beta 1 \text { concentrations at } 7 \\
\text { days and TGF- } \beta 1 \\
\text { amounts at } 14 \text { and } 180 \\
\text { days vs OFD. }\end{array}$ & $\begin{array}{l}\text { Powered for } \\
\text { clinical } \\
\text { outcomes }\end{array}$ & $\begin{array}{l}\text { Clinical and } \\
\text { radiographic } \\
\text { improvements noted for } \\
\text { all groups. EMD and } \\
\text { EMD + autograft } \\
\text { presented statistical } \\
\text { significantly higher } \\
\text { CAL gain and } \\
\text { radiographic defect fill } \\
\text { vs OFD. No significant } \\
\text { difference for EMD and } \\
\text { EMD + autograft. }\end{array}$ & $\begin{array}{l}\text { The trend for increased } \\
\text { TGF- } \beta 1 \text { expression } \\
\text { observed in EMD and } \\
\text { EMD + autograft } \\
\text { correlates with a } \\
\text { superior clinical } \\
\text { response, compared to } \\
\text { OFD. }\end{array}$ \\
\hline & $\begin{array}{l}\text { Ribeiro et al } \\
2011\end{array}$ & $\begin{array}{l}\text { TGF- } \beta 1 \text { levels } \\
\text { significantly increased } \\
\text { after } 15 \text { days and reduced } \\
\text { to baseline levels after } 3 \\
\text { months for MIST and } \\
\text { MIST + EMD. }\end{array}$ & $\begin{array}{l}\text { Similar changes in TGF- } \\
\beta 1 \text { levels were observed } \\
\text { for both groups, MIST } \\
\text { and MIST + EMD }\end{array}$ & $\begin{array}{l}\text { Powered for } \\
\text { clinical } \\
\text { outcomes }\end{array}$ & $\begin{array}{l}\text { Similar clinical and } \\
\text { radiographic } \\
\text { improvements were } \\
\text { noted for both groups }\end{array}$ & $\begin{array}{l}\text { Similar expression } \\
\text { patterns in TGF- } \beta 1 \\
\text { accompanied a similar } \\
\text { clinical response with } \\
\text { MIST and MIST + } \\
\text { EMD }\end{array}$ \\
\hline & $\begin{array}{l}\text { Kuru et al } \\
2004\end{array}$ & $\begin{array}{l}\text { TGF- } \beta 1 \text { levels increased } \\
\text { two-fold } 2 \text { weeks post-op } \\
\text { (not statistically } \\
\text { significant), declined to } \\
\text { levels lower than } \\
\text { baseline after } 4 \text { weeks } \\
\text { and remained stable until } \\
26 \text { weeks for GTR and } \\
\text { conventional flap }\end{array}$ & $\begin{array}{l}\text { TGF- } \beta 1 \text { levels were } \\
\text { similarly increased for } \\
\text { GTR and conventional } \\
\text { flap treated sites }\end{array}$ & $\begin{array}{l}\text { Power } \\
\text { calculation } \\
\text { not reported }\end{array}$ & $\begin{array}{l}\text { No statistically } \\
\text { significant differences } \\
\text { between GTR and } \\
\text { conventional flap noted } \\
\text { for clinical parameters } \\
6 \text { months post-op. }\end{array}$ & $\begin{array}{l}\text { Similar expression } \\
\text { patterns in TGF- } \beta 1 \\
\text { accompanied a similar } \\
\text { clinical response with } \\
\text { GTR and conventional } \\
\text { flap }\end{array}$ \\
\hline & $\begin{array}{l}\text { Pellegrini et } \\
\text { al } 2017\end{array}$ & $\begin{array}{l}\text { TGF- } \beta 1 \text { levels were } \\
\text { decreased compared to } \\
\text { baseline following } \\
\text { regeneration surgery }\end{array}$ & $\begin{array}{l}\text { A downward trend was } \\
\text { detected only after GTR } \\
\text { but not after OFD (non- } \\
\text { significant differences } \\
\text { between groups) }\end{array}$ & $\begin{array}{l}\text { No power } \\
\text { calculation } \\
\text { performed }\end{array}$ & $\begin{array}{l}\text { A higher percentage of } \\
\text { 'better responders 'in } \\
\text { terms of PD and CAL } \\
\text { was found in GTR vs } \\
\text { OFD. }\end{array}$ & $\begin{array}{l}\text { No conclusion can be } \\
\text { drawn for the } \\
\text { association of TGF- } \beta 1 \\
\text { with the clinical } \\
\text { outcome }\end{array}$ \\
\hline \multirow{3}{*}{ PDGF } & $\begin{array}{l}\text { Gamal et al } \\
2011\end{array}$ & $\begin{array}{l}\text { PDGF-BB concentrations } \\
\text { peaked during the early } \\
\text { post-op days (days } 2 \text { and } \\
3 \text { ) and decreased at } 7,14 \text {, } \\
\text { and } 30 \text { days in GTR and } \\
\text { OFD }\end{array}$ & $\begin{array}{l}\text { No significant difference } \\
\text { was found in PDGF-BB } \\
\text { concentrations between } \\
\text { GTR with periosteum } \\
\text { membrane and OFD } \\
\text { sites. }\end{array}$ & $\begin{array}{l}\text { Power } \\
\text { calculation } \\
\text { not reported }\end{array}$ & $\begin{array}{l}\text { GTR led to statistically } \\
\text { significantly higher } \\
\text { PPD reduction, CAL } \\
\text { gain and intrabony } \\
\text { component reduction vs } \\
\text { OFD. }\end{array}$ & $\begin{array}{l}\text { No conclusion can be } \\
\text { drawn for the } \\
\text { association of PDGF } \\
\text { levels with the clinical } \\
\text { outcome }\end{array}$ \\
\hline & $\begin{array}{l}\text { Gamal et al } \\
2016\end{array}$ & $\begin{array}{l}\text { PDGF-BB concentrations } \\
\text { at GTR with perforated } \\
\text { membranes and OFD } \\
\text { sites peaked during the } \\
\text { early stages of healing } \\
\text { (1-14 days) and then } \\
\text { decreased at } 21 \text { and } 30 \\
\text { days }\end{array}$ & $\begin{array}{l}\text { PDGF-BB levels at GTR } \\
\text { with perforated } \\
\text { membranes and OFD } \\
\text { sites showed statistically } \\
\text { significant higher levels } \\
\text { than GTR with occlusive } \\
\text { membrane at } 1,3,7,14 \\
\text { days. PDGF-BB levels } \\
\text { decreased gradually at } \\
\text { days } 21 \text { and } 30 \text { in all } \\
\text { groups with no } \\
\text { significant differences. }\end{array}$ & $\begin{array}{l}\text { Powered for } \\
\text { GCF markers } \\
\text { and clinical } \\
\text { outcomes }\end{array}$ & $\begin{array}{l}\text { GTR with perforated } \\
\text { membrane showed a } \\
\text { statistically significant } \\
\text { improvement in PPD, } \\
\text { CAL and intrabony } \\
\text { defect vs GTR with } \\
\text { occlusive membrane } \\
\text { and OFD. } \\
\text { GTR with occlusive } \\
\text { membrane-treated } \\
\text { resulted in significant } \\
\text { PPD reduction, CAL } \\
\text { gain and reduction of } \\
\text { the intrabony defect vs } \\
\text { OFD. }\end{array}$ & $\begin{array}{l}\text { No conclusion can be } \\
\text { drawn for the } \\
\text { association of PDGF } \\
\text { levels with the clinical } \\
\text { outcome }\end{array}$ \\
\hline & $\begin{array}{l}\text { Rakmanee } \\
\text { et al } 2018\end{array}$ & $\begin{array}{l}\text { PDGF-AB amount } \\
\text { increased early post-op } \\
\text { ( } 7 \text { days) and decreased to } \\
\text { baseline levels after } 42 \\
\text { days for GTR and access } \\
\text { surgery. }\end{array}$ & $\begin{array}{l}\text { Similar changes for } \\
\text { PDGF-AB were } \\
\text { observed for GTR and } \\
\text { access surgery. }\end{array}$ & $\begin{array}{l}\text { Powered for } \\
\text { clinical } \\
\text { outcomes }\end{array}$ & $\begin{array}{l}\text { No significant } \\
\text { differences for CAL } \\
\text { gain, PPD reduction, } \\
\text { radiographic bone fill } \\
\text { and radiographic defect } \\
\text { resolution noted for } \\
\text { GTR or access surgery. }\end{array}$ & $\begin{array}{l}\text { Similar expression for } \\
\text { PDGF-AB } \\
\text { accompanied a similar } \\
\text { clinical response after } \\
\text { GTR and access } \\
\text { surgery }\end{array}$ \\
\hline VEGF & Pellegrini et & VEGF levels increased 3 & Not reported & No power & Higher percentage of & No conclusion can be \\
\hline
\end{tabular}




\begin{tabular}{|c|c|c|c|c|c|c|}
\hline & al 2017 & weeks following GTR & & $\begin{array}{l}\text { calculation } \\
\text { performed }\end{array}$ & $\begin{array}{l}\text { "better responders 'was } \\
\text { found in GTR vs OFD. }\end{array}$ & $\begin{array}{l}\text { drawn for the } \\
\text { association of VEGF } \\
\text { levels with the clinical } \\
\text { outcome }\end{array}$ \\
\hline & $\begin{array}{l}\text { Gamal et al } \\
2016\end{array}$ & $\begin{array}{l}\text { VEGF concentrations } \\
\text { peaked during the early } \\
\text { post-op days (days 1-7) } \\
\text { and decreased at 14, } 21 \\
\text { and } 30 \text { days. }\end{array}$ & $\begin{array}{l}\text { VEGF concentrations } \\
\text { were significantly higher } \\
\text { for OFD and GTR with } \\
\text { perforated membrane } \\
\text { during the early post-op } \\
\text { days (days } 1,3 \text { and } 7 \text { ) vs } \\
\text { GTR with occlusive } \\
\text { membrane. }\end{array}$ & $\begin{array}{l}\text { Powered for } \\
\text { GCF markers } \\
\text { and clinical } \\
\text { outcomes }\end{array}$ & $\begin{array}{l}\text { GTR with perforated } \\
\text { membrane showed a } \\
\text { statistically significant } \\
\text { improvement in PPD, } \\
\text { CAL and intrabony } \\
\text { defect vs GTR with } \\
\text { occlusive membrane } \\
\text { and OFD. } \\
\text { GTR with occlusive } \\
\text { membrane showed a } \\
\text { significant PPD } \\
\text { reduction, CAL gain } \\
\text { and intrabony defect } \\
\text { reduction vs OFD }\end{array}$ & $\begin{array}{l}\text { No conclusion can be } \\
\text { drawn for the } \\
\text { association of VEGF } \\
\text { levels with the clinical } \\
\text { outcome }\end{array}$ \\
\hline & $\begin{array}{l}\text { Rakmanee } \\
\text { et al } 2018\end{array}$ & $\begin{array}{l}\text { In GTR and access } \\
\text { surgery, the VEGF } \\
\text { amount doubled early } \\
\text { post-op ( } 3-5 \text { days) and } \\
\text { decreased to baseline } \\
\text { levels after } 28 \text { days. }\end{array}$ & $\begin{array}{l}\text { No significant difference } \\
\text { was detected in the } \\
\text { change of VEGF for } \\
\text { GTR and access surgery }\end{array}$ & $\begin{array}{l}\text { Powered for } \\
\text { clinical } \\
\text { outcomes }\end{array}$ & $\begin{array}{l}\text { No significant } \\
\text { differences for CAL } \\
\text { gain, PPD reduction, } \\
\text { radiographic bone fill } \\
\text { and defect resolution } \\
\text { noted for GTR or } \\
\text { access surgery. The } \\
\text { total availability of } \\
\text { VEGF at } 30 \text { days } \\
\text { correlated with the } \\
\text { clinical changes }\end{array}$ & $\begin{array}{l}\text { Similar expression } \\
\text { patterns in the levels of } \\
\text { VEGF accompanied a } \\
\text { similar clinical response } \\
\text { with GTR and access } \\
\text { surgery }\end{array}$ \\
\hline \multirow[t]{3}{*}{ FGF } & $\begin{array}{l}\text { Pellegrini et } \\
\text { al } 2017\end{array}$ & $\begin{array}{l}\text { No significant change } \\
\text { was observed for FGF-2 } \\
\text { levels after OFD or GTR }\end{array}$ & Not reported & $\begin{array}{l}\text { No power } \\
\text { calculation } \\
\text { performed }\end{array}$ & $\begin{array}{l}\text { Higher percentage of } \\
\text { 'better responders 'was } \\
\text { found for GTR vs OFD. }\end{array}$ & $\begin{array}{l}\text { No conclusion can be } \\
\text { drawn for the } \\
\text { association of FGF with } \\
\text { the clinical outcome }\end{array}$ \\
\hline & Rakmanee & 3-5 days post- & No significant & Powered for & No significant & Similar expression \\
\hline & et al 2018 & $\begin{array}{l}\text { operatively, bFGF } \\
\text { amounts increased (not } \\
\text { statistically } \\
\text { significantly), peaked at } \\
7 \text { days and decreased to } \\
\text { baseline levels for GTR } \\
\text { and access surgery. }\end{array}$ & $\begin{array}{l}\text { differences in the bFGF } \\
\text { amount were noted } \\
\text { between GTR and access } \\
\text { surgery. }\end{array}$ & $\begin{array}{l}\text { clinical } \\
\text { outcomes }\end{array}$ & $\begin{array}{l}\text { differences for CAL } \\
\text { gain, PPD reduction, } \\
\text { radiographic bone fill } \\
\text { and radiographic defect } \\
\text { resolution were noted } \\
\text { for GTR or access } \\
\text { surgery. }\end{array}$ & $\begin{array}{l}\text { patterns in the bFGF } \\
\text { levels accompanied a } \\
\text { similar clinical response } \\
\text { with GTR and access } \\
\text { surgery }\end{array}$ \\
\hline \multirow[t]{2}{*}{ MMP-1 } & $\begin{array}{l}\text { Okuda et al } \\
2001\end{array}$ & $\begin{array}{l}\text { Intragroup analysis } \\
\text { showed a significant } \\
\text { decrease for MMP-1 } \\
\text { from } 2 \text { to } 4 \text { weeks after } \\
\text { surgery. } \\
\text { No significant changes } \\
\text { noted for MMP-1 levels } \\
\text { in the placebo group. }\end{array}$ & $\begin{array}{l}\text { Intergroup analysis } \\
\text { showed significantly } \\
\text { lower MMP-1 levels at } 2, \\
4 \text { and } 12 \text { weeks in EMD } \\
\text { vs placebo. }\end{array}$ & $\begin{array}{l}\text { Power } \\
\text { calculation } \\
\text { not reported }\end{array}$ & $\begin{array}{l}\text { Intragroup differences } \\
\text { between baseline and } \\
12 \text { weeks showed a } \\
\text { significant decrease in } \\
\text { PPD and CAL. } \\
\text { No significant } \\
\text { intergroup differences } \\
\text { noted. }\end{array}$ & $\begin{array}{l}\text { Despite the different } \\
\text { expression patterns in } \\
\text { the levels of MMP-1, a } \\
\text { similar clinical response } \\
\text { with EMD and control } \\
\text { was noted. }\end{array}$ \\
\hline & $\begin{array}{l}\text { Pellegrini et } \\
\text { al } 2017\end{array}$ & $\begin{array}{l}\text { MMP-1 levels increased } \\
\text { in 'worse responders' } \\
\text { and remained } \\
\text { substantially unchanged } \\
\text { in 'better } \\
\text { responders'. }\end{array}$ & Not reported & $\begin{array}{l}\text { No power } \\
\text { calculation } \\
\text { performed }\end{array}$ & $\begin{array}{l}\text { Higher percentage of } \\
\text { "better responders "was } \\
\text { found in GTR vs OFD. }\end{array}$ & $\begin{array}{l}\text { No conclusion can be } \\
\text { drawn for the } \\
\text { association of MMP-1 } \\
\text { levels with the clinical } \\
\text { outcome }\end{array}$ \\
\hline MMP-8 & $\begin{array}{l}\text { Okuda et al } \\
2001\end{array}$ & $\begin{array}{l}\text { Intragroup analysis } \\
\text { showed a significant } \\
\text { increase in MMP-8 for } \\
\text { EMD and control } \\
\text { significantly increased } \\
\text { at } 2 \text { weeks. There was a } \\
\text { decrease in MMP-8 } \\
\text { levels for EMD between } \\
2 \text { and } 4 \text { weeks and for } \\
\text { both groups between } 2\end{array}$ & $\begin{array}{l}\text { Intergroup analysis } \\
\text { demonstrated } \\
\text { significantly lower } \\
\text { MMP-8 levels for EMD } \\
\text { vs placebo at } 4 \text { and } 12 \\
\text { weeks }\end{array}$ & $\begin{array}{l}\text { Power } \\
\text { calculation } \\
\text { not reported }\end{array}$ & $\begin{array}{l}\text { Intragroup differences } \\
\text { between baseline and } \\
12 \text { weeks showed a } \\
\text { significant decrease in } \\
\text { PPD and CAL. } \\
\text { No significant } \\
\text { intergroup differences } \\
\text { were noted. }\end{array}$ & $\begin{array}{l}\text { Despite the different } \\
\text { expression patterns in } \\
\text { MMP-8 levels, a similar } \\
\text { clinical response with } \\
\text { EMD and control was } \\
\text { noted. }\end{array}$ \\
\hline TIMP-1 & $\begin{array}{l}\text { Okuda et al } \\
2001\end{array}$ & $\begin{array}{l}\text { Both EMD and placebo, } \\
\text { presented a significant } \\
\text { increase in TIMP-1 }\end{array}$ & $\begin{array}{l}\text { Intergroup analysis } \\
\text { demonstrated } \\
\text { significantly lower mean }\end{array}$ & $\begin{array}{l}\text { Power } \\
\text { calculation } \\
\text { not reported }\end{array}$ & $\begin{array}{l}\text { Intragroup differences } \\
\text { between baseline and } \\
12 \text { weeks showed a }\end{array}$ & $\begin{array}{l}\text { Despite the different } \\
\text { expression patterns in } \\
\text { the levels of TIMP-1, a }\end{array}$ \\
\hline
\end{tabular}




\begin{tabular}{|c|c|c|c|c|c|c|}
\hline & & $\begin{array}{l}\text { between baseline and } 2 \\
\text { weeks. } \\
\text { Significant decreases in } \\
\text { TIMP-1 levels at } 4 \text { and } \\
12 \text { weeks when } \\
\text { compared to } 2 \text { weeks } \\
\text { were noted for both } \\
\text { groups. }\end{array}$ & $\begin{array}{l}\text { levels of TIMP-1 at } 4 \\
\text { weeks for EMD } \\
\text { vs placebo }\end{array}$ & & $\begin{array}{l}\text { significant decrease in } \\
\text { PPD and CAL. } \\
\text { No significant } \\
\text { intergroup differences } \\
\text { were noted. }\end{array}$ & $\begin{array}{l}\text { similar clinical response } \\
\text { with EMD and control } \\
\text { was noted. }\end{array}$ \\
\hline & $\begin{array}{l}\text { Pellegrini et } \\
\text { al } 2017\end{array}$ & $\begin{array}{l}\text { Following GTR, a trend } \\
\text { for increased TIMP-1 } \\
\text { levels was observed }\end{array}$ & Not reported & $\begin{array}{l}\text { No power } \\
\text { calculation } \\
\text { performed }\end{array}$ & $\begin{array}{l}\text { Higher percentage of } \\
\text { "better responders 'was } \\
\text { found for GTR vs OFD. }\end{array}$ & $\begin{array}{l}\text { No conclusion can be } \\
\text { drawn for the } \\
\text { association of TIMP-1 } \\
\text { levels with the clinical }\end{array}$ \\
\hline & $\begin{array}{l}\text { Rakmanee } \\
\text { et al } 2018\end{array}$ & $\begin{array}{l}\text { 3-5 days post-op, TIMP- } \\
1 \text { amounts increased } \\
\text { significantly for GTR, } \\
\text { access flap or control } \\
\text { sites. At } 7 \text { days, TIMP-1 } \\
\text { amount decreased to } \\
\text { baseline levels for GTR, } \\
\text { while access surgery sites } \\
\text { presented reduced levels }\end{array}$ & $\begin{array}{l}\text { No significant } \\
\text { differences in TIMP-1 } \\
\text { amount were noted for } \\
\text { GTR and access surgery. }\end{array}$ & $\begin{array}{l}\text { Powered for } \\
\text { clinical } \\
\text { outcomes }\end{array}$ & $\begin{array}{l}\text { No significant } \\
\text { differences for CAL } \\
\text { gain, PPD reduction, } \\
\text { radiographic bone fill } \\
\text { and radiographic defect } \\
\text { resolution were noted } \\
\text { for GTR or access } \\
\text { surgery. }\end{array}$ & $\begin{array}{l}\text { Similar expression } \\
\text { patterns in levels of } \\
\text { TIMP-1 accompanied a } \\
\text { similar clinical response } \\
\text { with GTR and access } \\
\text { surgery }\end{array}$ \\
\hline Ang-1 & $\begin{array}{l}\text { Rakmanee } \\
\text { et al } 2018\end{array}$ & $\begin{array}{l}\text { 3-5 days post-op, Ang-1 } \\
\text { amounts increased } \\
\text { significantly, peaked at } 7 \\
\text { days and decreased to } \\
\text { baseline levels for GTR. } \\
\text { For access flap, Ang-1 } \\
\text { amount increased by } 7 \\
\text { days and declined to } \\
\text { baseline levels. }\end{array}$ & $\begin{array}{l}\text { No significant } \\
\text { differences in Ang-1 } \\
\text { amount between GTR } \\
\text { and access surgery. }\end{array}$ & $\begin{array}{l}\text { Powered for } \\
\text { clinical } \\
\text { outcomes }\end{array}$ & $\begin{array}{l}\text { No significant } \\
\text { differences for CAL } \\
\text { gain, PPD reduction, } \\
\text { radiographic bone fill } \\
\text { and radiographic defect } \\
\text { resolution were noted } \\
\text { between GTR and } \\
\text { access surgery. }\end{array}$ & $\begin{array}{l}\text { Similar expression } \\
\text { patterns in the levels of } \\
\text { Ang-1 accompanied a } \\
\text { similar clinical response } \\
\text { with GTR and access } \\
\text { surgery }\end{array}$ \\
\hline
\end{tabular}

\section{FACTORS RELATED WITH THE HEALING OF BONE}

\begin{tabular}{|c|c|c|c|c|c|c|}
\hline GCF marker & $\begin{array}{l}\text { Investigato } \\
\mathbf{r}, \text { Year }\end{array}$ & $\begin{array}{l}\text { Is periodontal surgery } \\
\text { leading to significant } \\
\text { changes in the } \\
\text { expression of GCF } \\
\text { markers? }\end{array}$ & $\begin{array}{l}\text { Is there any } \\
\text { significant difference } \\
\text { in the expression of } \\
\text { GCF markers for } \\
\text { intrabony defects } \\
\text { treated with GTR vs } \\
\text { OFD? }\end{array}$ & $\begin{array}{l}\text { Is the study } \\
\text { powered for } \\
\text { GCF } \\
\text { markers, for } \\
\text { clinical } \\
\text { outcomes or } \\
\text { both? }\end{array}$ & $\begin{array}{l}\text { Is there any significant } \\
\text { difference in the clinical } \\
\text { response for intrabony } \\
\text { defects treated with GTR } \\
\text { vs OFD? }\end{array}$ & $\begin{array}{l}\text { Is the expression of GCF } \\
\text { markers directly } \\
\text { associated with clinically } \\
\text { significant changes } \\
\text { following treatment? }\end{array}$ \\
\hline \multirow{3}{*}{ OPG } & $\begin{array}{l}\text { Ribeiro et al } \\
2011\end{array}$ & $\begin{array}{l}\text { Significant increases for } \\
\text { OPG noted after } 15 \\
\text { days, but no differences } \\
\text { observed after } 3 \text { months }\end{array}$ & $\begin{array}{l}\text { Similar changes in OPG } \\
\text { levels observed for both } \\
\text { groups, MIST and } \\
\text { MIST + EMD }\end{array}$ & $\begin{array}{l}\text { Powered for } \\
\text { clinical } \\
\text { outcomes }\end{array}$ & $\begin{array}{l}\text { Similar clinical and } \\
\text { radiographic } \\
\text { improvements were noted } \\
\text { for both groups }\end{array}$ & $\begin{array}{l}\text { Similar expression patterns } \\
\text { in the levels of OPG } \\
\text { accompanied a similar } \\
\text { clinical response with } \\
\text { MIST and MIST + EMD }\end{array}$ \\
\hline & $\begin{array}{l}\text { Rakmanee } \\
\text { et al } 2018\end{array}$ & $\begin{array}{l}\text { OPG amount } \\
\text { significantly increased } \\
\text { (2-fold) 3-5 days post- } \\
\text { op for GTR and } \\
\text { declined. A non- } \\
\text { significant increase was } \\
\text { noted for access } \\
\text { surgery. }\end{array}$ & $\begin{array}{l}\text { Similar OPG levels } \\
\text { were observed for both } \\
\text { groups, GTR and access } \\
\text { surgery, that were } \\
\text { significantly higher } \\
\text { than healthy control } \\
\text { sites }\end{array}$ & $\begin{array}{l}\text { Powered for } \\
\text { clinical } \\
\text { outcomes }\end{array}$ & $\begin{array}{l}\text { No significant differences } \\
\text { for CAL gain, PPD } \\
\text { reduction, radiographic } \\
\text { bone fill and radiographic } \\
\text { defect resolution were } \\
\text { noted for GTR and access } \\
\text { surgery. }\end{array}$ & $\begin{array}{l}\text { Similar expression patterns } \\
\text { in the levels of OPG } \\
\text { accompanied a similar } \\
\text { clinical response with } \\
\text { GTR and access surgery }\end{array}$ \\
\hline & $\begin{array}{l}\text { Pellegrini et } \\
\text { al } 2017\end{array}$ & $\begin{array}{l}\text { OPG levels were } \\
\text { decreased after GTR } \\
\text { and OFD. }\end{array}$ & Not reported & $\begin{array}{l}\text { No power } \\
\text { calculation } \\
\text { performed }\end{array}$ & $\begin{array}{l}\text { Higher percentage of } \\
\text { 'better responders 'was } \\
\text { found in GTR vs OFD. }\end{array}$ & $\begin{array}{l}\text { No conclusion can be } \\
\text { drawn for the association } \\
\text { of OPG levels with the } \\
\text { clinical outcome. }\end{array}$ \\
\hline OCN & $\begin{array}{l}\text { Ribeiro et al } \\
2011\end{array}$ & $\begin{array}{l}\text { No significant changes } \\
\text { were noted for OCN } \\
\text { levels up to } 3 \text { months } \\
\text { post-op }\end{array}$ & $\begin{array}{l}\text { No significant changes } \\
\text { for OCN levels were } \\
\text { observed for any group. }\end{array}$ & $\begin{array}{l}\text { Powered for } \\
\text { clinical } \\
\text { outcomes }\end{array}$ & $\begin{array}{l}\text { Similar clinical and } \\
\text { radiographic } \\
\text { improvements were noted } \\
\text { for both groups }\end{array}$ & $\begin{array}{l}\text { No conclusion can be } \\
\text { drawn for the association } \\
\text { of OCN levels with the } \\
\text { clinical outcome. }\end{array}$ \\
\hline \multirow[t]{2}{*}{ BMP-2 } & $\begin{array}{l}\text { Rakmanee } \\
\text { et al } 2018\end{array}$ & $\begin{array}{l}\text { 3-5 days post-op, BMP- } \\
2 \text { amounts increased } \\
\text { (significantly for GTR), }\end{array}$ & $\begin{array}{l}\text { No significant } \\
\text { differences in the BMP- } \\
2 \text { amount between GTR }\end{array}$ & $\begin{array}{l}\text { Powered for } \\
\text { clinical } \\
\text { outcomes }\end{array}$ & $\begin{array}{l}\text { No significant differences } \\
\text { for CAL gain, PPD } \\
\text { reduction, radiographic }\end{array}$ & $\begin{array}{l}\text { Similar expression patterns } \\
\text { in the levels of BMP-2 } \\
\text { accompanied a similar }\end{array}$ \\
\hline & & $\begin{array}{l}\text { peaked at } 7 \text { days and } \\
\text { decreased to baseline } \\
\text { levels for GTR and } \\
\text { access surgery }\end{array}$ & $\begin{array}{l}\text { and access surgery were } \\
\text { noted. }\end{array}$ & & $\begin{array}{l}\text { bone fill and radiographic } \\
\text { defect resolution were } \\
\text { noted between defects } \\
\text { treated with GTR or access } \\
\text { surgery. }\end{array}$ & $\begin{array}{l}\text { clinical response with } \\
\text { GTR and access surgery }\end{array}$ \\
\hline BMP-7 & $\begin{array}{l}\text { Pellegrini et } \\
\text { al } 2017\end{array}$ & $\begin{array}{l}\text { BMP-7 levels tended to } \\
\text { increase for 'better } \\
\text { responders' (by means } \\
\text { of PD and CAL) and to } \\
\text { decrease for 'worse } \\
\text { responders'. }\end{array}$ & Not reported & $\begin{array}{l}\text { No power } \\
\text { calculation } \\
\text { performed }\end{array}$ & $\begin{array}{l}\text { Higher percentage of } \\
\text { 'better responders' was } \\
\text { found for GTR vs OFD. }\end{array}$ & $\begin{array}{l}\text { No conclusion can be } \\
\text { drawn for the association } \\
\text { of BMP-7 levels with the } \\
\text { clinical outcome }\end{array}$ \\
\hline
\end{tabular}


OTHER GCF FACTORS

\begin{tabular}{|c|c|c|c|c|c|c|}
\hline GCF marker & $\begin{array}{l}\text { Investigato } \\
\mathbf{r} \text {, Year }\end{array}$ & $\begin{array}{l}\text { Is periodontal surgery } \\
\text { leading to significant } \\
\text { changes in the } \\
\text { expression of GCF } \\
\text { markers? }\end{array}$ & $\begin{array}{l}\text { Is there any } \\
\text { significant difference } \\
\text { in the expression of } \\
\text { GCF markers for } \\
\text { intrabony defects }\end{array}$ & $\begin{array}{l}\text { Is the study } \\
\text { powered for } \\
\text { GCF } \\
\text { markers, for } \\
\text { clinical }\end{array}$ & $\begin{array}{l}\text { Is there any significant } \\
\text { difference in the } \\
\text { clinical response for } \\
\text { intrabony defects } \\
\text { treated with GTR vs }\end{array}$ & $\begin{array}{l}\text { Is the expression of } \\
\text { GCF markers directly } \\
\text { associated with } \\
\text { clinically significant } \\
\text { changes following }\end{array}$ \\
\hline & & & $\begin{array}{l}\text { treated with GTR vs } \\
\text { OFD? }\end{array}$ & $\begin{array}{l}\text { outcomes or } \\
\text { both? }\end{array}$ & OFD? & treatment? \\
\hline PAF & $\begin{array}{l}\text { Keles et al } \\
2006\end{array}$ & $\begin{array}{l}\text { Significant decreases in } \\
\text { PAF levels for GTR } \\
\text { and flap surgery were } \\
\text { noted at } 6,12 \text { and } 24 \\
\text { weeks post-operatively } \\
\text { compared to pre- } \\
\text { surgery }\end{array}$ & $\begin{array}{l}\text { No significant } \\
\text { differences in PAF } \\
\text { levels } \\
\text { between the study } \\
\text { groups pre-operatively } \\
\text { and at } 6,12 \text { and } 24 \\
\text { weeks postoperatively } \\
\text { were noted }\end{array}$ & $\begin{array}{l}\text { Power } \\
\text { calculation } \\
\text { not reported }\end{array}$ & $\begin{array}{l}\text { Both treatment } \\
\text { modalities significantly } \\
\text { reduced the PPD and } \\
\text { improved the CAL. No } \\
\text { significant differences } \\
\text { were observed between } \\
\text { the groups. }\end{array}$ & $\begin{array}{l}\text { Similar expression } \\
\text { patterns in the levels of } \\
\text { expression of PAF } \\
\text { accompanied a similar } \\
\text { clinical response with } \\
\text { GTR and flap surgery }\end{array}$ \\
\hline sICAM-1 & $\begin{array}{l}\text { Kuru et al } \\
2005\end{array}$ & $\begin{array}{l}\text { For sites treated with } \\
\text { GTR and conventional } \\
\text { flap, the total amount of } \\
\text { sICAM-1 increased } \\
\text { during the initial 2-4 } \\
\text { weeks (non- } \\
\text { significantly) and then } \\
\text { reduced at a lower level } \\
\text { than baseline up to } 12 \\
\text { weeks }\end{array}$ & $\begin{array}{l}\text { No significant } \\
\text { differences in sICAM- } \\
1 \text { amount between the } \\
\text { groups were noted }\end{array}$ & $\begin{array}{l}\text { Power } \\
\text { calculation } \\
\text { not reported }\end{array}$ & Not reported & $\begin{array}{l}\text { No conclusion can be } \\
\text { drawn for the } \\
\text { association of the } \\
\text { sICAM-1 levels with } \\
\text { the clinical outcome. }\end{array}$ \\
\hline sLFA-3 & $\begin{array}{l}\text { Kuru et al } \\
2005\end{array}$ & $\begin{array}{l}\text { For sites treated with } \\
\text { GTR and conventional } \\
\text { flap, the total amount of } \\
\text { sLFA- } 3 \text { significantly } \\
\text { increased at } 2 \text { weeks } \\
\text { and thereby returned to } \\
\text { baseline levels }\end{array}$ & $\begin{array}{l}\text { No significant } \\
\text { differences in } \\
\text { sLFA-3 amount } \\
\text { between the groups } \\
\text { were noted }\end{array}$ & $\begin{array}{l}\text { Power } \\
\text { calculation } \\
\text { not reported }\end{array}$ & Not reported & $\begin{array}{l}\text { No conclusion can be } \\
\text { drawn for the } \\
\text { association of the } \\
\text { sLFA-3 levels with the } \\
\text { clinical outcome. }\end{array}$ \\
\hline
\end{tabular}

\begin{tabular}{|l|l|l|l|l|l|}
\hline & No significant difference between & & Significant difference between & & Data is Inconclusive \\
\hline & groups & groups & & \\
\hline
\end{tabular}

were localised at anterior teeth, compared with the majority of the sites treated with OFD that were localised at molar teeth.

Okuda et al. described an increase for matrix metalloproteinase-8 (MMP-8) and metallopeptidase inhibitor 1 (TIMP-1) GCF levels 2 weeks postoperatively for defects treated with EMD and OFD that thereafter declined, more dramatically for EMD-treated defects [23]. MMP-1 levels significantly decreased from 2 to 4 weeks postoperatively for defects treated with EMD [23].

Ribeiro et al. using Periopaper in the gingival crevice for $30 \mathrm{~s}$ concluded that OPG levels increase 15 days postoperatively and similar changes are noted after both MIST and MIST with EMD [20]. Interestingly, Rakmanee et al. concluded that the OPG amount significantly increased 2-3 days postoperatively and subsequently declined with no significant differences between sites treated with GTR and OFD [24]. Consequently, similar changes were noted for the OPG levels after MIST and MIST with EMD or after GTR and access flap. Furthermore, both studies reported similar clinical and radiographic improvements for both treatment groups [20, 24]; thus, the similar expression patterns in the levels of expression of OPG accompanied a similar clinical response, irrespective of the surgical technique employed.

\section{GTR and EMD}

Regarding the combination of GTR and EMD, Agrali et al. reported on the levels of TGF- $\beta 1$. The combination-treated defects, similarly distributed to anterior and posterior teeth, presented similar changes in the TGF- $\beta 1$ levels as the EMDtreated defects in the first 2 postoperative weeks [19]. The similar changes of TGF- $\beta 1$ levels accompanied a similar clinical response for EMD and EMD with GTR, that was superior to OFD. However, as discussed previously the majority of the defects treated with OFD were localised in posterior teeth.

\section{OFD}

Finally, regarding OFD alone, there is agreement between two investigations that an increase in TGF- $\beta 1$ levels is initially observed, accompanied by a return to baseline levels by 14 days 
$[19,26]$. For PDGF, conflicting results are presented; Gamal and co-workers reported an initial increase and a decrease by 7 days postoperatively to below baseline levels [11]. In contrary, another investigation from the same group reported a decrease for the PDGF levels that continued until 30 days postoperatively [21]. Rakmanee et al. noted an increase in the PDGF amount after OFD that continued until 3 months postoperatively [24].

For the remaining markers and for more detail regarding the expression of the investigated GCF markers after the surgical treatments, the reader is referred to the detailed Table 2.

\section{Risk of bias assessment}

The risk of bias assessment is presented in Fig. 2 and Table 3. Seven of the included studies (RCTs) were assessed using the Cochrane Collaboration tool [11, 19-24]. Four of the seven studies were of low risk of bias in all but one domain [11, 20, $22,24]$, two were of low risk of bias in five domains [21, 24] and one [19] was of high risk of bias. The remaining three studies $[12,25,26]$ were prospective cohort studies and were assessed using the MINORS tool. These studies were rated with 16 to 18 , indicating high quality of the included studies.

\section{Discussion}

This systematic review identified 15 GCF markers expressed after surgical treatment of intrabony defects (GTR, OS, OFD). For 7 of those, most of which are related with the healing of connective tissue, TGF- $\beta 1$, PDGF, VEGF, FGF, MMP-1, TIMP-1 and OPG, data was available from more than one investigation. While for the majority of factors a definitive conclusion cannot be reached, robust suggestions can be drawn regarding the OPG levels in regenerative surgeries. In two investigations, employing different GCF sampling and storing techniques, the OPG levels after MIST or MIST with EMD and after GTR or access flap similarly increased within the two postoperative weeks and thereafter declined [20, 24]. Furthermore, both studies reported similar clinical and radiographic improvements; thus, the similar expression patterns of OPG likely accompanied a similar clinical response. OPG acts as a soluble decoy receptor, binding to the receptor activator of nuclear factor-kappa B (RANKL) and inhibiting the osteoclastogenic action [27]. Therefore, OPG has been identified as a critical factor in bone formation and the regulation of bone resorption.

The finding of this review however comes in contrast with a human polymerase chain reaction (PCR) study assessing the
Fig. 2 Risk of bias assessment of RCTs using the Cochrane

Collaboration tool
Agrali, 2016.

Gamal, 2016.

Ribeiro, 2011

Gamal, 2011.

Keles, 2006

Okuda, 2001

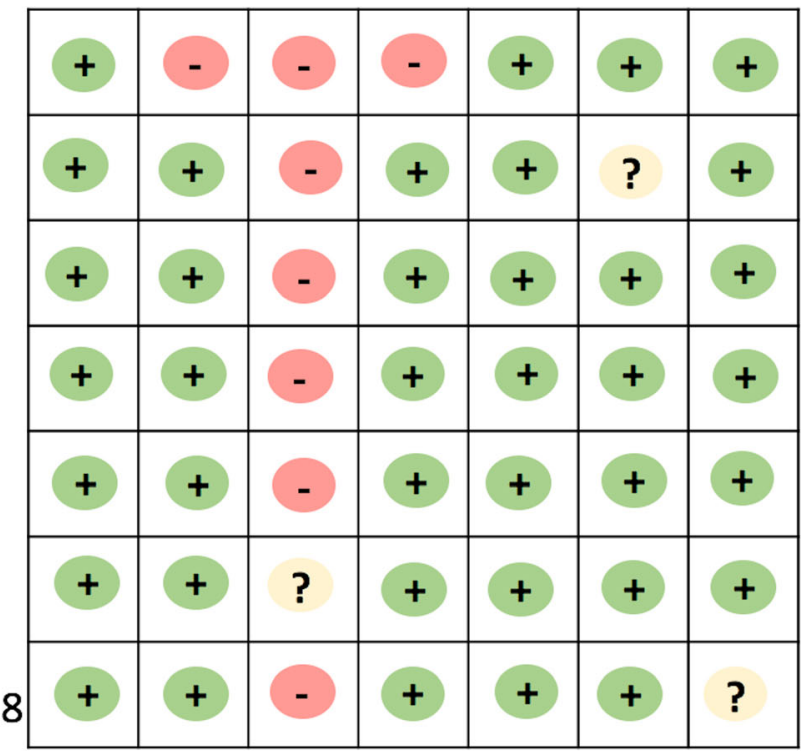

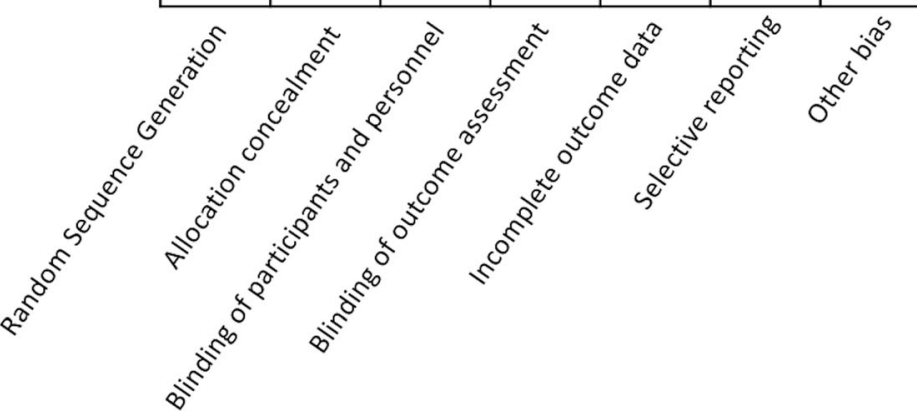


Table 3 Risk of bias assessment of observational studies using the MINORS tool. Studies were assessed in 12 items and can receive $0-2$ points for each for a total score ranging from 0 to 24 points. Studies with fewer than 16 points are considered of low quality while high quality studies need to have a score of greater than or equal to 16

\begin{tabular}{llll}
\hline Minors tool & $\begin{array}{l}\text { Kuru L, J } \\
\text { Periodontol. 2005 }\end{array}$ & $\begin{array}{l}\text { Kuru L, J Clin } \\
\text { Periodontol. 2004 }\end{array}$ & $\begin{array}{l}\text { Pellegrini, J Periodont } \\
\text { Res 2017 }\end{array}$ \\
\hline A clearly stated aim & 2 & 2 & 2 \\
Inclusion of consecutive patients & 0 & 0 & 0 \\
$\begin{array}{l}\text { Prospective collection of data } \\
\text { End points appropriate to the }\end{array}$ & 2 & 2 & 2 \\
$\quad 2$ & 2 & 2 \\
$\quad$ aim of the study & & 0 & 0 \\
$\quad$ study end point & 0 & 2 & 2 \\
Follow-up period appropriate to the & 2 & 2 & 1 \\
$\quad$ aim of the study & 2 & 0 & 0 \\
Loss to follow-up < 5\% & 0 & 2 & 2 \\
Prospective calculation of & 2 & 2 & 2 \\
$\quad$ the study size & 2 & 2 & 1 \\
An adequate control group & 0 & 2 & 2 \\
Contemporary groups & 2 & 18 & 16 \\
Baseline equivalence of groups & 16 & & \\
Adequate statistical analyses & & 2 &
\end{tabular}

gene modulation 21 days following treatment of intrabony defects with either GTR with an expanded polytetrafluorethylene (ePTFE) membrane or flap surgery [28]. Among others, OPG mRNA levels were significantly higher in GTR sites, compared with access flap sites. Furthermore, in an investigation of the gene expression profile of cells derived from GTR subjected defects (regenerating-tissue derived cells-RTCs), a differential and highlighted expression of the gene encoding OPG (TNFRSF11B) was found compared with matched periodontal ligament mesenchymal cells (PLCs) [29]. These contrasting results may be due to the high rate of exposures (13/18 GTR sites) in the study by Rakmanee et al. that may have significantly affected the regenerative process and thus the OPG expression [24]. In addition, the Ribeiro et al. investigation, as most of the included studies, was not powered for GCF and could therefore lack statistical power to detect differences in the expression levels between treatments [20].

Interestingly, Okuda et al. found that the use of EMD in intrabony defects resulted in an early postoperative increase for MMP-8 and TIMP-1, followed by an accelerated return to baseline levels, when compared to OFD [23]. This highlighted reduction may associate with an EMD-induced accelerated pattern of wound healing and resolution of inflammation moving towards regeneration rather than repair.

With respect to PDGF, three isoforms exist (AA, AB, BB). Two studies included in this review $[11,24]$ demonstrated that GTR and access flap lead to similar changes: an initial increase of PDGF-BB [11] and PDGF-AB [24] during the early healing period (up to 7 days), accompanied by a decrease to baseline levels. Two PDGF receptors exist, the PDGF-R $\alpha$ and the PDGF-R $\beta$ who binds PDGF-AB with low and PDGF-BB with high affinity [30]. In contrast with the included in this review studies, a significant upregulation of PDGF-R $\beta$ in regenerating periodontal tissues has been observed [31] suggesting that the ligands are involved in the early cascade of events involved in regeneration.

Furthermore, in the only study powered for GCF markers [21], perforated PTFE membranes were shown to result in significantly higher VEGF during the early healing period (1, 3 and 7 days) when compared to occlusive membranes. In an animal model of GTR using porcine extracellular matrix (ECM), membrane cells recruited early postoperatively into the membrane compartment result in highlighted expression of, among other factors, VEGF at the RNA level. The VEGF expression was significantly highlighted 3 days postoperatively and thereby decreased by 28 days [32]. This VEGF upregulation, along with other regenerative molecules, early postoperatively in the mRNA and the protein level, may suggest that the membrane itself acts as a bioactive compartment guiding the regenerative process and not solely as an active barrier.

TGF- $\beta 1$ is a connective tissue cell signalling protein that plays a critical role in several stages of wound healing, as it promotes the mitogenic activity of gingival and periodontal ligament cells and the upregulation of extracellular matrix components $[33,34]$. With regards to TGF- $\beta 1$, the existing literature is conflicting. The studies included in this review studies suggest that the clinical and radiographic outcome may be related to the TGF- $\beta 1$ level changes [20, 26]. Ribeiro et al and Kuru et al showed that GTR or OFD and MIST or EMD treatments exhibited similar TGF- $\beta 1$ increase early post-operatively, as well as similar clinical and radiographic improvements $[20,26]$. However, the significant clinical and radiographic improvement following EMD in Agrali's study was associated with a significant TGF- $\beta 1$ increase for EMD at anterior teeth, 
in contrast with OFD at mainly posterior teeth [19]. When OFD was employed alone for the treatment of intrabony defects, two investigations agreed that an increase in TGF- $\beta 1$ levels is initially observed, accompanied by a return to baseline levels by 14 days $[19,26]$. In the same line, in an immunocytochemistry investigation in biopsies, a highlighted increase was noted for TGF- $\beta 1$ receptor in regenerating periodontal tissues (6 weeks), while the receptor was almost undetectable in healthy tissues [31]. The highlighted receptor presence in regenerating tissues may suggest that the corresponding TGF- $\beta 1$ plays a pivotal role in the early healing.

As it became evident, an important limitation was that only one of the ten included studies [21] was powered to detect significant differences in the GCF markers, whereas the remaining nine studies were either powered for the clinical outcomes or did not report any power calculation. Furthermore, inclusion of intrabony defects with varying number of defect walls does not allow for meaningful conclusions as regeneration is more likely to occur in 3-walled defects and to be accompanied by a different array of GCF markers compared to a 1-wall defect. In addition, reportedly, a large variation across investigations was observed in the methodology employed for the GCF sampling, storage and detection. These variations would introduce confounders if a meta-analysis was attempted. For example, the sampling methods (Periopaper, micropipette), the duration of collection (30 s, 2 min, until a specific volume is collected), the depth of strip insertion (entrance of the pocket or full depth), the storage (temperature) or the preparation of the samples (processing individual or pooled samples) introduce variations that would affect the conclusions drawn and their generalisability. Furthermore, it becomes imperative that more well-designed, powered studies with sampling periods reflecting the regenerative process are needed. Future investigations should employ standardised protocols for GCF sampling, processing and storage.

In conclusion:

There is limited evidence available on the expression of markers of angiogenesis, regeneration and inflammation in the GCF in the early and late healing after surgical interventions of intrabony periodontal defects

OPG is increased early postoperatively, irrespective of the surgical technique employed

A trend is noted for TGF- $\beta 1$ increase early postoperatively, irrespective of the surgical technique employed. A highlighted increase is noted after use of EMD at anterior teeth that may relate with an improved clinical outcome.

More well-designed, powered studies with sampling periods reflecting the regenerative process are needed

Future research should focus on employing standardised protocols for collecting, storing and analysing GCF markers and establishing adequate statistical power to reach conclusions that may shed light in the biological events involved in the early periodontal wound healing and thus facilitate the development of predictable regenerative treatments

\section{Compliance with ethical standards}

Conflict of interest The authors declare that they have no conflict of interest.

Ethical approval This article does not contain any studies with human participants or animals performed by any of the authors.

Informed consent For this type of study, formal consent is not required.

Open Access This article is distributed under the terms of the Creative Commons Attribution 4.0 International License (http:// creativecommons.org/licenses/by/4.0/), which permits unrestricted use, distribution, and reproduction in any medium, provided you give appropriate credit to the original author(s) and the source, provide a link to the Creative Commons license, and indicate if changes were made.

\section{References}

1. Eke PI, Dye BA, Wei L, Slade GD, Thornton-Evans GO, Borgnakke WS, Taylor GW, Page RC, Beck JD, Genco RJ (2015) Update on prevalence of periodontitis in adults in the United States: NHANES 2009 to 2012. J Periodontol 86(5):611-622

2. Papapanou PN, Wennstrom JL (1991) The angular bony defect as indicator of further alveolar bone loss. J Clin Periodontol 18:317322

3. Cobb CM (1996) Non-surgical pocket therapy: mechanical. Ann Periodontol 1:443-490

4. Heitz-Mayfield LJ, Trombelli L, Heitz F, Needleman I, Moles D (2002) A systematic review of the effect of surgical debridement vs non-surgical debridement for the treatment of chronic periodontitis. J Clin Periodontol 29(Suppl 3):92-102

5. Graziani F, Karapetsa D, Mardas N, Leow N, Donos N (2018) Surgical treatment of the residual periodontal pocket. Periodontol 2000 76(1):150-163

6. Aichelmann-Reidy ME, Reynolds MA (2008 Mar) Predictability of clinical outcomes following regenerative therapy in intrabony defects. J Periodontol 79(3):387-393

7. Murphy KG, Gunsolley JC (2003) Guided tissue regeneration for the treatment of periodontal intrabony and furcation defects. A systematic review. Ann Periodontol 8(1):266-302

8. Esposito M, Grusovin MG, Papanikolaou N, Coulthard P, Worthington HV (2009) Enamel matrix derivative (Emdogain $®$ ) for periodontal tissue regeneration in intrabony defects. Cochrane Database Syst Rev 7(4):CD003875

9. Koop R, Merheb J, Quirynen M (2012) Periodontal regeneration with enamel matrix derivative in reconstructive periodontal therapy: a systematic review. J Periodontol 83(6):707-720

10. Miron RJ, Sculean A, Cochran DL, Froum S, Zucchelli G, Nemcovsky C, Donos N, Lyngstadaas SP, Deschner J, Dard M, Stavropoulos A, Zhang Y, Trombelli L, Kasaj A, Shirakata Y, Cortellini P, Tonetti M, Rasperini G, Jepsen S, Bosshardt DD (2016) Twenty years of enamel matrix derivative: the past, the present and the future. J Clin Periodontol 43:668-683

11. Gamal AY, El-Shal OS, El-Aasara MM, Fakhry EM (2011) Plateletderived growth factor-BB release profile in gingival crevicular fluid after use of marginal periosteal pedicle graft as an autogenous guided tissue membrane to treat localized intrabony defects. J Periodontol 82(2):272-280

12. Pellegrini G, Rasperini G, Pagni G, Giannobile WV, Milani S, Musto F, Dellavia C (2017) Local wound healing biomarkers for 
real-time assessment of periodontal regeneration: pilot study. J Periodontal Res 52:388-396

13. Moher D, Liberati A, Tetzlaff J, Altman DG, PRISMA Group (2009) Preferred reporting items for systematic reviews and metaanalyses: the PRISMA statement. J Clin Epidemiol 62(10):10061012. https://doi.org/10.1016/j.jclinepi.2009.06.005

14. Lang N, Bartold PM, Cullinan M et al (1999) Consensus report: aggressive periodontitis. Ann Periodontol 4:53

15. Armitage GC (1999) Development of a classification system for periodontal diseases and conditions. Ann Periodontol 4:1-6

16. Tonetti M, Greenwell H, Kornmann K (2018) Staging and grading of periodontitis: framework and proposal of a new classification and case definition. J Periodontol 89(Suppl1):S159-S172

17. Higgins JPT, Green S (2011) Cochrane handbook for systematic reviews of interventions version 5.1.0. The Cochrane Collaboration, London

18. Slim K, Nini E, Forestier D, Kwiatkowski F, Panis Y, Chipponi J (2003) Methodological index for non-randomised studies (minors): development and validation of a new instrument. ANZ J Surg 73(9):712-716

19. Agrali ÖB, Kuru BE, Yarat A, Kuru L (2016) Evaluation of gingival crevicular fluid transforming growth factor- $\beta 1$ level after treatment of intrabony periodontal defects with enamel matrix derivatives and autogenous bone graft: a randomised controlled clinical trial. Niger J Clin Pract 19(4):535-543

20. Ribeiro FV, Casarin RC, Júnior FH, Sallum EA, Casati MZ (2011) The role of enamel matrix derivative protein in minimally invasive surgery in treating intrabony defects in single-rooted teeth: a randomised clinical trial. J Periodontol 82(4):522-532

21. Gamal AY, Abdel-Ghaffar KA, Iacono VJ (2016) Gingival crevicular fluid vascular endothelial cell growth factor and plateletderived growth factor-BB release profile following the use of perforated barrier membranes during treatment of intrabony defects: a randomised clinical trial. J Periodontal Res 51(3):407-416

22. Keles GC, Cetinkaya BO, Isildak I, Koprulu H, Acikgoz G (2006) Levels of platelet activating factor in gingival crevice fluid following periodontal surgical therapy. J Periodontal Res 41(6):513-518

23. Okuda K, Miyazaki A, Momose M, Murata M, Nomura T, Kubota T, Wolff LF, Yoshie H (2001) Levels of tissue inhibitor of metalloproteinases- 1 and matrix metalloproteinases- 1 and -8 in gingival crevicular fluid following treatment with enamel matrix derivative (EMDOGAIN). J Periodontal Res 36(5):309-316
24. Rakmanee T, Calciolari E, Olsen I, Darbar U, Griffiths GS, Petrie A, Donos N (2018) Expression of growth mediators in the gingival crevicular fluid of patients with aggressive periodontitis undergoing periodontal surgery. Clin Oral Investig 23:3307-3318. https://doi. org/10.1007/s00784-018-2752-z

25. Kuru L, Kirby AC, Griffiths GS, Petrie A, Olsen I (2005) Changes in soluble adhesion molecules in gingival crevicular fluid following periodontal surgery. J Periodontol 76(4):526-533

26. Kuru L, Griffiths GS, Petrie A, Olsen I (2004) Changes in transforming growth factor-betal in gingival crevicular fluid following periodontal surgery. J Clin Periodontol 31(7):527-533

27. Jin Q, Cirelli JA, Park CH, Sugai JV, Taba M Jr, Kosteunuik PJ, Giannobile WV (2007) RANKL inhibition through osteoprotegerin blocks bone loss in experimental periodontitis. J Periodontol 78(7): $1300-1308$

28. Lima LL, Goncalves PF, Sallum EA, Casati MZ, Nociti FH Jr (2008) Guided tissue regeneration may modulate gene expression in periodontal intrabony defects; a human study. J Periodontal Res 43:459-464

29. Ivanovski S, LIchanska AM, D'Aniello E, Xiao Y, Waters MJ (2007) Gene expression profiling of cells involved in periodontal regeneration. Tissue Eng 13(2):393-404

30. Raines EW, Ross R (1990) Platelet-derived growth factor. In: Sporn $\mathrm{AB}$, Roberts $\mathrm{AB}$ (eds) Polypeptide growth factors and their receptors. Springer, New York, pp 173-262

31. Parkar MH, Kuru L, Giouzeli M, Olsen I (2001) Expression of growth factor receptors in normal and regenerating human periodontal wells. Arch Oral Biol 46:275-284

32. Turi A, Elgali I, Vazirisani F et al (2016) Guided bone regeneration is promoted by the molecular events in the membrane compartment. Biomaterials 84:167-183

33. Dennison DK, Vallone DR, Pinero GJ, Rittman B, Caffesse RG (1994) Differential effect of TGF-beta 1 and PDGF on proliferation of periodontal ligament cells and gingival fibroblasts. J Periodontol 65(7):641-648

34. Matsuda N, Lin WL, Kumar NM, Cho MI, Genco RJ (1992) Mitogenic, chemotactic, and synthetic responses of rat periodontal ligament fibroblastic cells to polypeptide growth factors in vitro. J Periodontol 63(6):515-525

Publisher's note Springer Nature remains neutral with regard to jurisdictional claims in published maps and institutional affiliations. 